\title{
Penerapan Social Network Analysis dalam Penentuan Centrality Studi Kasus Social Network Twitter
}

\author{
Budi Susanto ${ }^{1}$ \\ budsus@ti.ukdw.ac.id
}

\author{
Herlina $^{2}$ \\ 22084595@students.ukdw.ac.id
}

\author{
Antonius R. C. ${ }^{3}$ \\ anton@ti.ukdw.ac.id
}

\begin{abstract}
The twitter provides a kind of relation between users in specific form. When someone follow others, it doesn't mean that she/he know well about them. We have defined a friend relationship between users in twitter as connection following and follower between two users. Based on this definition we develop a system to get friends and also friends of friends relation from a specific user. We use twitter API to get following and follower list and then construct a graph that represent a social network between those users. From this graph, we analyse the centrality using SNA (Social Network Analysis) method, i.e. closeness and betweeness. We propose to use these methods in order to find out who is the most influence user in the his/her social network to spread out the tweet or information. With this system, user can know about their social network based on their friend list on twitter.
\end{abstract}

Kata Kunci : Social Network Analysis, Betweenness Centrality, Closeness Centrality

\section{PENDAHULUAN}

Dengan berkembangnya teknologi arsitektur Web 2.0, telah banyak bermunculan aplikasi yang lebih interaktif antara user dan aplikasi, sekaligus mendukung pengembangan aplikasi yang mendukung interaksi antar user. Aplikasi yang sangat banyak berkembang adalah aplikasi media sosial. Dengan aplikasi ini sangat dimungkinkan untuk kemudian dianalisis terkait dengan berbagai segi terhadap jejaring sosial yang terbentuk.

Twitter adalah salah satu aplikasi media sosial online yang sangat diminati dengan menempati urutan ke 2 terbesar di dunia. (Berdasarkan laporan yang dikeluarkan oleh TechCrunch dari data Social Media Examiner. Laman berita diakses di http://techcrunch.com/2011/12/22/googlesplus/?utm_source=feedburner\&utm_medium=feed\&u tm_campaign=Feed\%3A+Techcrunch+\%28TechCrunch\%29 tanggal 21 Juni 2012). Dengan jumlah user yang besar sekali, maka akan sangat sulit untuk dapat menemukan bentuk jejaring

\footnotetext{
${ }^{1}$ Teknik Informatika, Fakultas Teknologi Informasi, Universitas Kristen Duta Wacana, Yogyakarta

${ }^{2}$ Teknik Informatika, Fakultas Teknologi Informasi, Universitas Kristen Duta Wacana, Yogyakarta

${ }^{3}$ Teknik Informatika, Fakultas Teknologi Informasi, Universitas Kristen Duta Wacana, Yogyakarta
} 
sosial dan menganalisisnya dengan pendekatan manual. Relasi atau hubungan antar individu yang terjalin dalam aplikasi twitter dapat menjadi sangat kompleks.

Berdasar ulasan yang pernah diungkapkan oleh Huberman, Romero, dan Wu (2009) dalam penelitiannya tentang interaksi akun di twitter dengan interaksi sosial sesungguhnya, dinyatakan bahwa jumlah teman yang sesungguhnya hanya sekitar $13 \%$ dari jumlah mengikuti ataupun diikuti yang terdeklarasi di twitter. Walaupun demikian, dalam penelitian ini kami tetap menerapkan suatu asumsi bahwa definisi "teman" dalam jejaring di Twitter adalah jika seorang akun mem-follow akun orang lain demikian juga sebaliknya. Sehingga antar dua akun tersebut akan terbentuk dua node dengan dua edge berarah yang saling menunjuk. Dengan asumsi ini, kami akan melakukan penyaringan dari daftar akun yang diikuti (following) dengan daftar akun yang mengikutinya (follower).

Sebagai contoh adalah penulis (dengan nama akun @budsus) sendiri memiliki akun dengan jumlah follower adalah 596 dan jumlah yang penulis follow adalah sebanyak 334. Dari jumlah tersebut jika disaring hanya yang kami sebut sebagai teman, yaitu menyaring dengan cara mencari himpunan irisan yang ada di himpunan following dan juga muncul di himpunan follower, diperoleh sebanyak 131 teman. Kondisi ini jika dibentuk graph akan membentuk sebuah topologi star dengan sentarnya adalah@budsus. Setelah dikembangkan untuk diambil semua daftar teman dari teman @ budsus (pada level berikutnya), diperoleh total sebanyak 8180 akun yang berbeda (termasuk akun teman @budsus langsung. Jika kondisi ini digambarkan jejaringanya, maka akan diperoleh sebuah graph yang sangat komplek (Gambar 1). Visualisasi graph Gambar 1 menggunakan bantuan aplikasi Gephi (gephi.org) dengan bentuk layout Yifan Hu. Walaupun sudah melakukan penyaringan ini, jumlah node dan bentuk graph tetap sangat komplek dan untuk menganalisisnya diperlukan suatu sistem

Social Network Analysis merupakan studi yang mempelajari tentang hubungan manusia dengan memanfaatkan teori graf. Melihat permasalahan di atas, penerapan Social Network Analysis dalam suatu aplikasi yang mampu menggambarkan relasi atau hubungan antar individu dengan melakukan visualisasi dalam bentuk graf kiranya dapat membantu proses pemecahan masalah yang ada. Selain itu, akan dilakukan proses kalkulasi terhadap setiap relasi antar individu untuk menemukan centrality dari sebuah jejaring sosial yang didasarkan pada posisi masing-masing individu yang terkait dalam struktur jaringan. Dengan aplikasi ini, tiap individu dapat menganalisa jaringan sosial yang telah mereka bangun dan mengetahui centrality dari struktur jalinan relasi yang dimiliki oleh masing-masing individu. 


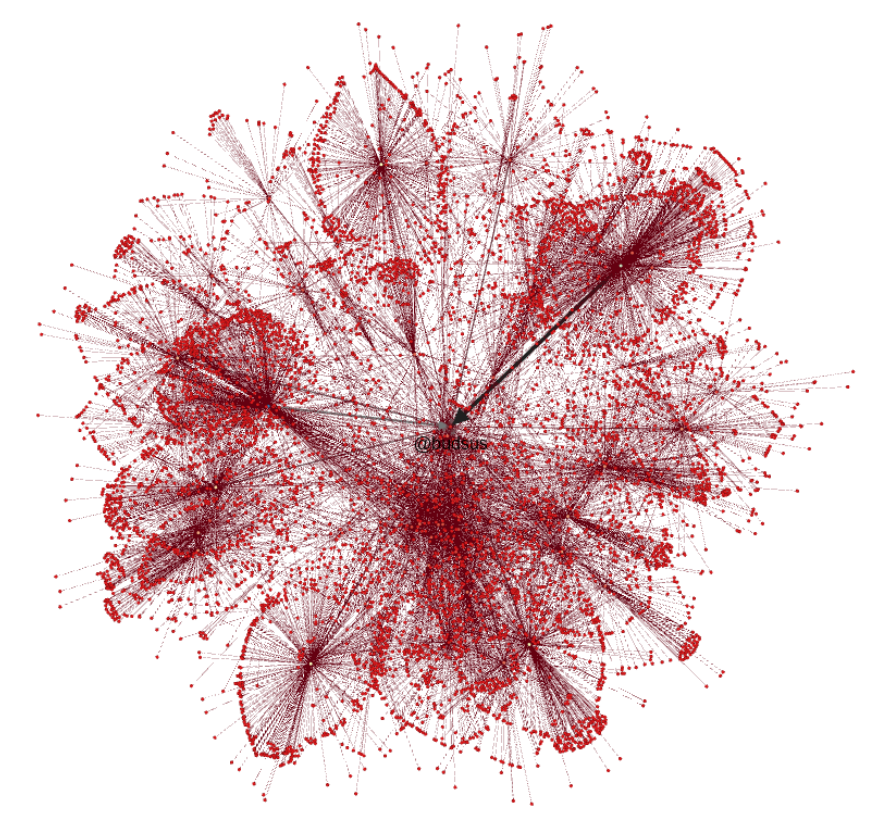

Gambar 1. Contoh Jejaring Sosial dari akun @budsus

Penelitian ini bertujuan untuk membangun sebuah aplikasi berbasis web untuk menemukan centrality berdasa pendekatan betweenness centrality dan closeness centrality dari sebuah jejaring sosial yang didasarkan pada posisi masing-masing individu yang terkait dalam struktur jaringan. Selain itu, aplikasi ini juga akan melakukan visualisasi dalam bentuk graf terhadap hubungan-hubungan yang ada. Sehingga dengan adanya aplikasi ini, pengguna tidak perlu merasakan kesulitan untuk menganalisa jaringan sosial yang dimiliki.

\section{LANDASAN TEORI}

\subsection{Social Network Analysis (SNA)}

Social Network Analysis (SNA) dapat dideskripsikan sebagai sebuah studi yang mempelajari tentang hubungan manusia dengan memanfaatkan teori graf. (Tsvetovat \& Kouznetsov, 2011, hal 1). Dengan pemanfaatan teori graf ini membuat SNA mampu memeriksa struktur dari hubungan sosial dalam suatu kelompok untuk mengungkap hubungan informal antar individu.

Pada social network, individu atau orang digambarkan sebagai nodes atau titik, sedangkan relasi yang terjadi antar individu disebut dengan edges atau links. Pada dasarnya sebuah jaringan sosial adalah sebuah peta yang terdiri atas banyak orang dimana di dalamnya terdapat relasi antar individunya. Berikut adalah contoh pemetaan graf dari sebuah jaringan sosial. 


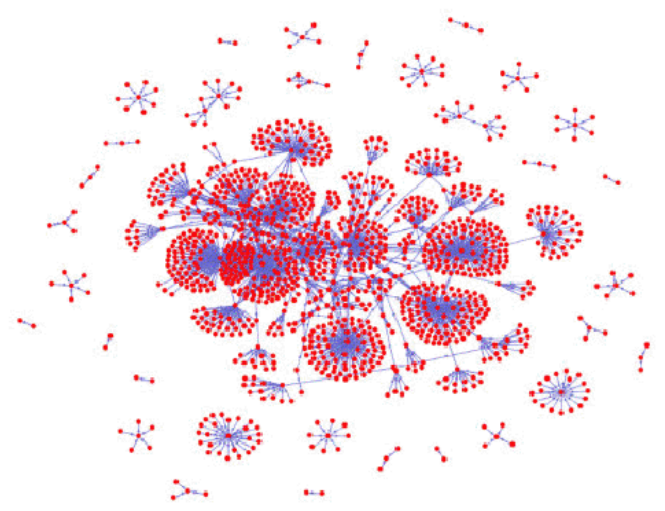

Gambar 2. Social Network

Dikutip dari : Kazienko, P. \& Musial, K. (2005). Social Networks. (http://www.ii.pwr.wroc.pl/ kazienko/pub/2005/social\%20networks.pdf)

\subsection{Graf}

Ada 2 macam cara untuk merepresentasikan informasi yang ada, yaitu dengan menggunakan graf dan matriks. Dari sekian banyak jenis graf yang ada, network analysis menggunakan suatu jenis graf yang berisi nodes atau titik untuk merepresentasikan aktor dan edges atau garis untuk merepresentasikan hubungan atau relasi, yang disebut "socio-grams".

Penggambaran sebuah hubungan dalam graf yang disimbolkan dengan menggunakan edges atau garis terdapat dua cara, yaitu dengan directed graph dan simple atau bonded-tie graph. Simple atau bonded-tie graph merupakan graf sederhana yang menghubungkan sepasang aktor yang memiliki hubungan, hanya saja edges atau garis yang digunakan tanpa menggunakan anak panah. Directed graph adalah graf yang mampu menunjukkan relasi lebih jelas, karena relasi yang disimbolkan dengan edges atau garis digambarkan dengan anak panah. Pada penelitian ini akan digunakan undirected graph untuk menggambarkan relasi antar individu.

\subsubsection{Matriks Adjacency}

Jenis matriks yang biasa digunakan dalam analisa jaringan sosial adalah matriks adjacency. Nilai yang ada di tiap cell menunjukkan informasi atas hubungan atau relasi antar aktor atau individu. Matriks adjacency sangat berguna untuk melihat kedekatan antar aktor atau individu berdasarkan nilai yang ada di tiap cell. Pada penelitian ini skala pengukuran akan menggunakan binary yang hanya memiliki nilai 0 dan 1 . Nilai 0 akan merepresentasikan tidak adanya hubungan, sedangkan nilai 1 merepresentasikan adanya hubungan antar aktor atau individu tertentu.

Ada 2 tipe matriks adjacency, yaitu symmetric dan asymmetric. Sebuah jaringan sosial dapat terdiri dari 2 tipe ini. Jika terdapat relasi pertemanan antara Bob, Carol, Alice dan Ted, digambarkan bahwa Bob menjalin relasi dengan Carol, tetapi Carol tidak. Maka dari itu, matriks 
$\mathrm{X}_{\mathrm{ij}}$ tidak mungkin sama dengan matriks $\mathrm{X}_{\mathrm{ji}}$, inilah yang disebut dengan asymmetric (seperti pada tabel 1). Namun lain halnya dengan Bob dengan Ted, Carol dengan Ted, dan Alice dengan Ted yang menjalin relasi timbal balik, maka matriks $X_{\mathrm{ij}}$ sama dengan matriks $X_{\mathrm{ji}}$, sehingga relasi ini dapat disebut dengan symmetric.

\section{Tabel 1.}

Asymmetric Adjacency Matrix

Dikutip dari : Hanneman (2005). Introduction to Social Network Methods. http://faculty.ucr.edu/ hanneman/nettext/C1_Social_Network_Data.html

\begin{tabular}{|l|c|c|c|c|}
\hline & Bob & Carol & Ted & Alice \\
\hline Bob & --- & 1 & 1 & 0 \\
\hline Carol & 0 & --- & 1 & 0 \\
\hline Ted & 1 & 1 & --- & 1 \\
\hline Alice & 0 & 0 & 1 & --- \\
\hline
\end{tabular}

\subsubsection{Algoritma Djikstra}

Menurut Puntambekar definisi Algoritma Dijkstra adalah “... algoritma populer untuk mencari jalur terpendek. Algoritma ini disebut dengan single source shortest path." (2008, hlm. 27). Algoritma Dijkstra tidak hanya sekedar mencari jalur dari lokasi awal menuju lokasi tujuan, tetapi juga mencari jalur terpendek dari seluruh kemungkinan jalur yang ada. Berikut adalah contoh kasus dari Algoritma Dijkstra.

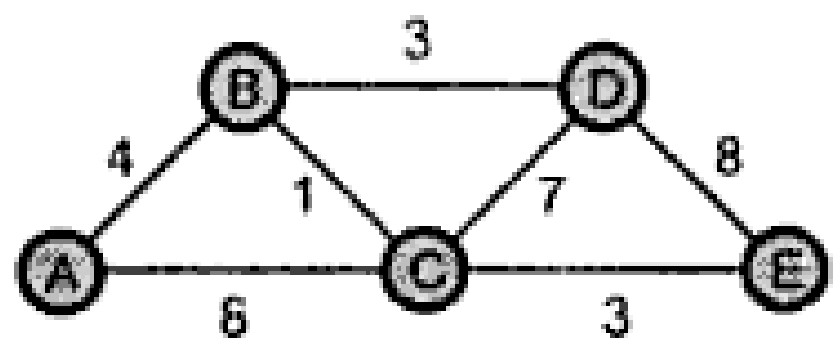

Gambar 3. Contoh Kasus Algoritma Dijkstra

Dikutip dari : Puntambekar, A. A. (2002). Analysis and Design of Algorithms, hlm. 28.

Pada contoh pada gambar 3, lokasi awal adalah node A, dan lokasi tujuan akhir adalah node E. Setiap node terhubung dengan node lain melalui sebuah edge yang memiliki nilai jarak berupa bilangan bulat positif. Langkah pertama yang dilakukan adalah mencari jarak dari node A ke seluruh node yang terhubung dengan node $\mathrm{A}$, yaitu node $\mathrm{B}$ dan node $\mathrm{C}$. Kemudian langkah berikutnya adalah mencari jarak dari node $\mathrm{B}$ menuju ke seluruh node yang terhubung dengan node $\mathrm{B}$, yaitu node $\mathrm{C}$ dan node $\mathrm{D}$. Proses ini terus berlangsung hingga seluruh node telah dijelajahi. 


\subsubsection{Centrality}

Dalam teori graf dan network analysis, terdapat empat cara untuk mengukur centrality, yaitu dengan cara menghitung degree centrality, betweeness centrality, closeness centrality dan eigenvector centrality. Pada penelitian ini akan digunakan dua cara perhitungan, yaitu betweeness centrality dan closeness centrality.

Betweenness centrality adalah salah satu cara untuk mengukur centrality dalam suatu jaringan sosial. Berikut adalah rumus untuk menghitung nilai betweenness centrality setiap node dalam jaringan.

$$
\begin{aligned}
& C_{B}\left(v_{i}\right)=\sum_{\substack{v_{s} \neq v_{i} \neq v_{i} \in V, s<t \\
\sigma_{s t}}} \frac{\sigma_{s t}\left(v_{i}\right)}{\sigma_{s t}} \\
& \sigma_{\mathrm{st}}=\text { jumlah jalur terpendek dari s ke } \mathrm{t} \\
& \sigma_{\mathrm{st}}\left(\mathrm{v}_{\mathrm{i}}\right) \quad=\text { jumlah jalur terpendek dari s ke } \mathrm{t} \text { yang melewati simpul } \mathrm{v} .
\end{aligned}
$$

Closeness centrality adalah salah satu cara untuk mengukur centrality dalam suatu jaringan sosial yang fokus terhadap seberapa dekat suatu aktor dengan semua aktor lainnya. Berikut adalah rumus untuk menghitung nilai closeness centrality setiap node dalam jaringan.

$$
\begin{aligned}
& C_{C}\left(v_{i}\right)=\frac{n-1}{\sum_{j \neq i}^{n} g\left(v_{i}, v_{j}\right)} \\
& \mathrm{g}\left(\mathrm{v}_{\mathrm{i}}, \mathrm{v}_{\mathrm{j}}\right)=\text { jarak antara node } \mathrm{v}_{\mathrm{i}} \text { dan } \mathrm{v}_{\mathrm{j}} \\
& \mathrm{n}=\text { jumlah node yang terdapat di dalam jaringan }
\end{aligned}
$$

\section{HASIL DAN PEMBAHASAN}

\subsection{Perancangan}

Pada gambar 4 dijelaskan bahwa aplikasi akan dibangun berbasis web yang nantinya akan berhubungan dengan web service yang telah disediakan oleh jejaring sosial Twitter untuk mendapatkan data akun dan relasinya.

Alur kerja sistem ini dimulai dari aplikasi web yang meminta pengguna untuk menginputkan username akun Twitter. Inputan pengguna berfungsi sebagai parameter awal yang digunakan oleh aplikasi web untuk melakukan request ke web service untuk mendapatkan data akun Twitter dan relasi yang telah dibangun oleh pengguna. Sebagai response, web service akan mengembalikan data akun dan relasinya sesuai dengan inputan parameter yang dikirim pada saat melakukan request. Data akun dan relasi yang sesuai dengan inputan pengguna tersebut akan diolah, sehingga aplikasi web mampu memvisualisasikan relasi yang telah terbentuk dalam bentuk graf dan menampilkan hasil dari perhitungan centrality dari relasi pengguna yang telah terbentuk. 


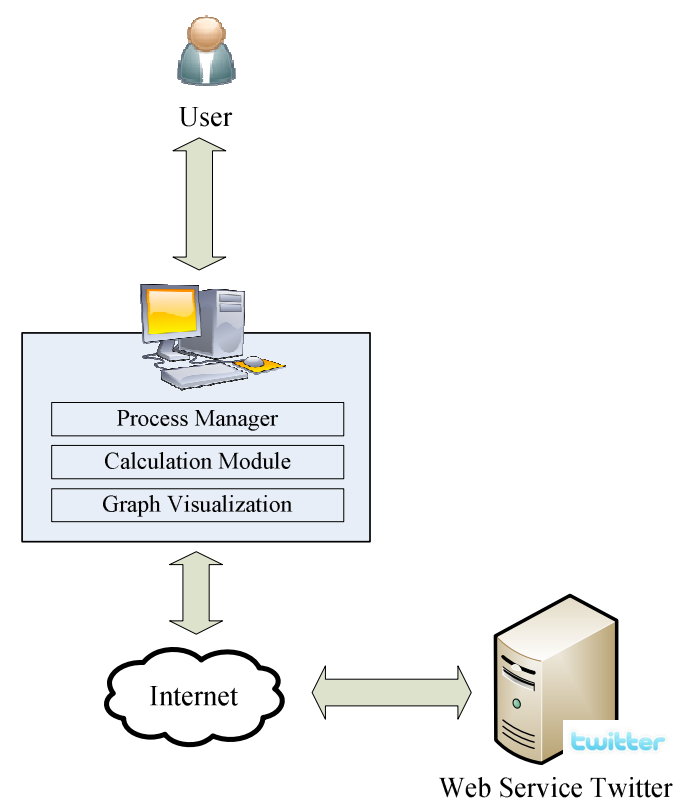

Gambar 4. Rancangan Arsitektur Sistem

\subsection{Antarmuka}

Aplikasi ini dibangun dengan berbasis web yang diberi nama "describeMe". Saat pengguna mengakses halaman web, aplikasi akan memberikan uraian singkat mengenai manfaat dari aplikasi bagi pengguna.

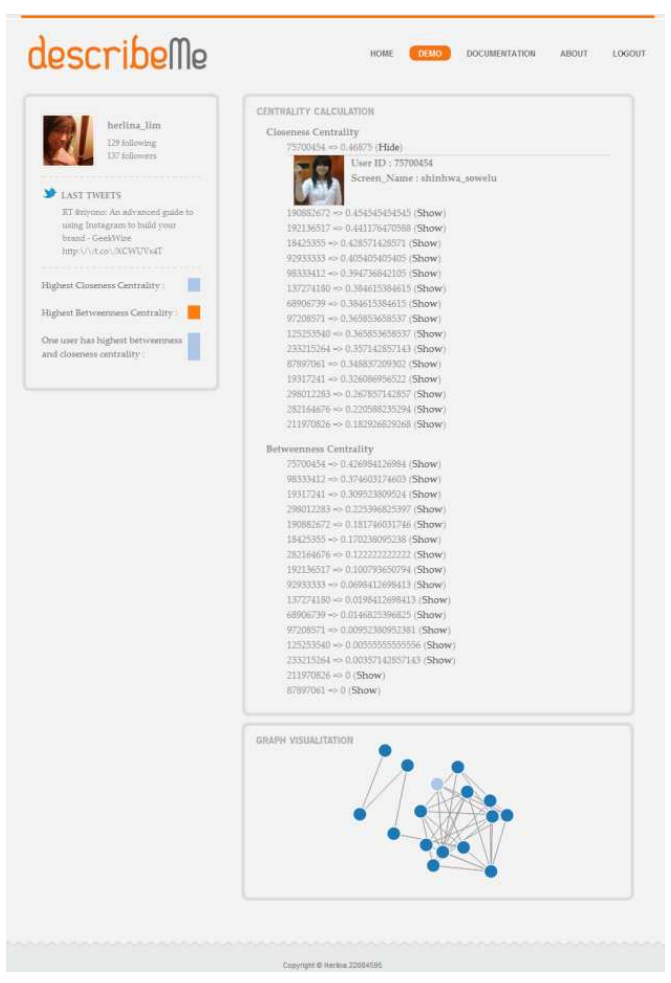

Gambar 5. Halaman Demo Setelah Memasukkan Username 
Pada halaman awal aplikasi terdapat 3 menu, yaitu demo, documentation dan about. Halaman demo merupakan halaman yang akan melakukan perhitungan centrality dan visualisasi relasi dalam bentuk graf terhadap sejumlah data friends yang dimiliki oleh pengguna berdasarkan screen_name akun Twitter yang diinputkan. Setelah pengguna memasukkan username, aplikasi akan memulai proses perhitungan centrality dan visualisasi relasi dalam bentuk graf (seperti gambar 5).

Halaman documentation merupakan halaman yang memberikan informasi mengenai betweenness centrality dan closeness centrality kepada calon pengguna aplikasi agar calon pengguna memahami terlebih dahulu istilah-istilah yang digunakan dalam aplikasi. Berbeda dengan halaman documentation, halaman about merupakan halaman yang memberikan informasi mengenai maksud dan tujuan dibangunnya sebuah aplikasi yang dinamakan describeMe.

\subsection{Analisis dan Pengujian}

Analisa yang dilakukan adalah bagaimana suatu node dapat memiliki nilai closeness centrality dan betweenness centrality paling tinggi. Pengujian dilakukan pada akun Twitter dengan screen_name herlina_lim yang memiliki 126 following dan 131 followers. Dari jumlah following dan follower yang dimiliki diambil sekumpulan data yang mewakili perhitungan centrality. Berikut adalah daftar akun Twitter yang akan dihitung nilai centrality-nya.

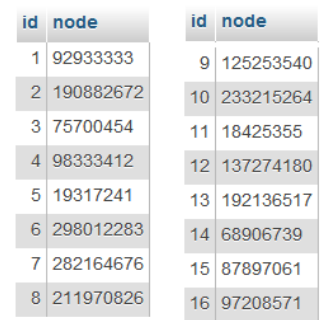

Gambar 6. Daftar Akun Twitter : Hasil dari Pengumpulan Node dari Akun Twitter Milik herlina_lim

Daftar akun Twitter yang telah dikumpulkan tersebut akan dicari relasi atau hubungannya dengan akun Twitter yang lainnya. Pada gambar 6, node adalah user_id dari pemilik akun Twitter. Akun Twitter direpresentasikan sebagai node di dalam jaringan, sedangkan relasi direpresentasikan sebagai edge. Hasil pencarian relasi nantinya akan digunakan untuk membantu dalam menggambarkan visualisasi relasi yang terjadi dari sekumpulan node yang terkumpul dalam bentuk graf. Berikut adalah hasil dari pencarian relasi antar node dengan node lainnya. 


\section{Tabel 2.}

Relasi Antar Node : Akun Twitter herlina_lim sebagai Node Awal

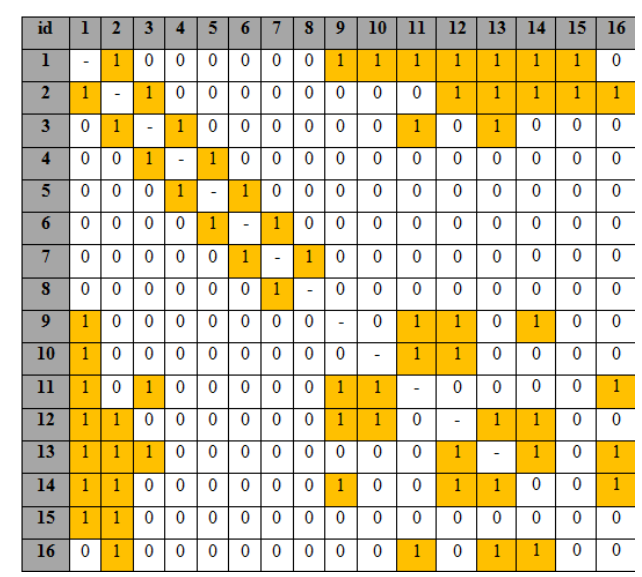

Dengan memanfaatkan hasil relasi pada Tabel 2, visualisasi relasi yang terjadi antar node dapat digambarkan dalam bentuk graf. Gambar 7 adalah visualisasi relasi yang mampu digambarkan oleh sistem sesuai dengan data relasi yang sebelumnya telah disimpan di database pada tabel relasi.

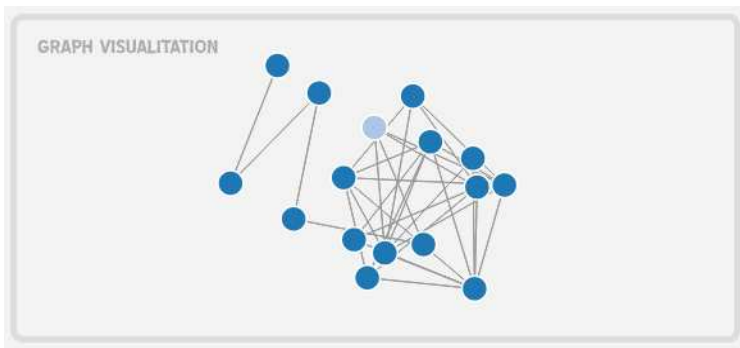

Gambar 7. Visualisasi Relasi : Akun Twitter herlina_lim sebagai Node Awal

\subsubsection{Betweenness Centrality}

Gambar 8 merupakan hasil perhitungan betweenness centrality sesuai dengan daftar node (seperti gambar 6) dan data relasi (seperti Tabel 2). Dari hasil perhitungan tersebut dapat diketahui bahwa yang memiliki nilai betweenness centrality paling tinggi adalah akun Twitter dengan $u s e r \_i d 75700454$, yaitu sebesar 0.42698413 .

Akun Twitter dengan user_id 75700454 memiliki nilai betweenness centrality paling tinggi karena node ini berada di antara dua kelompok besar di dalam jaringan. Seperti terlihat pada gambar 9, node 75700454 (node dengan id =3) mampu menghubungkan kelompok 1 yang terdiri dari node dengan user_id 98333412 (node dengan id =4), 19317241 (node dengan id = 5), 298012283 (node dengan id =6), 282164676 (node dengan id =7), dan 211970826 (node dengan id =8) dan kelompok 2 yang terdiri dari node dengan user_id 190882672 (node dengan $\mathrm{id}=2$ ), 125253540 (node dengan id = 9), 233215264 (node dengan id =10), 18425355 (node 
dengan id = 11), 137274180 (node dengan id = 12), 192136517 (node dengan $\mathrm{id}=13$ ), 68906739 (node dengan id =14), 87897061 (node dengan id =15), 97208571 (node dengan id = 16). Node 75700454 (node dengan id = 3) yang memiliki nilai betweenness centrality paling tinggi ini tentunya menduduki posisi yang paling penting atau paling kuat di dalam jaringan.

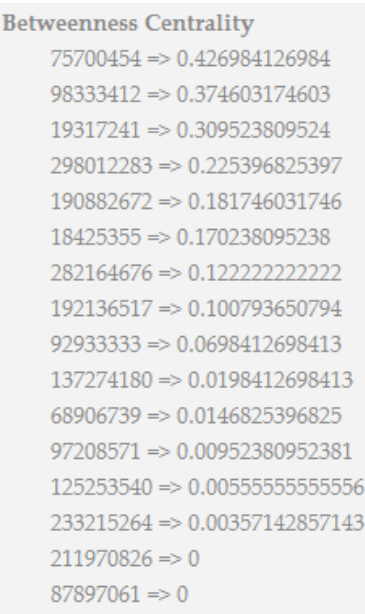

Gambar 8. Betweenness Centrality: Akun Twitter herlina_lim sebagai Node Awal

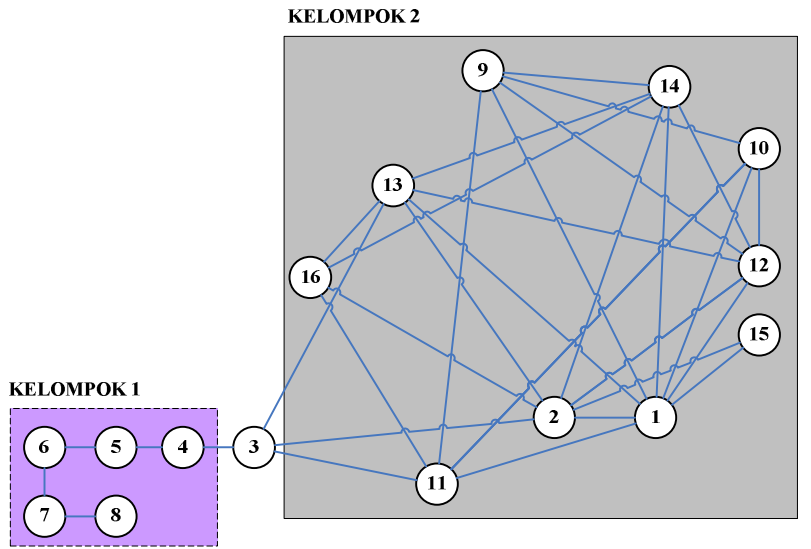

Gambar 9. Betweenness Centrality: Akun Twitter herlina_lim sebagai Node Awal

Node 75700454 memiliki pengaruh yang cukup besar terhadap apa yang terjadi di dalam jaringan karena dengan adanya node ini di dalam jaringan, kelompok 1 dan kelompok 2 menjadi terhubung. Jika node ini tidak terdapat di dalam jaringan, tentunya akan menghilangkan hubungan antar node dari kelompok 1 dan kelompok 2. Pada gambar 10 terlihat jelas bahwa ketika node 75700454 dihapus atau dihilangkan dari jaringan, maka jaringan tidak menjadi satu kesatuan lagi, yakni terpisah menjadi dua jaringan, yaitu jaringan pertama adalah jaringan yang anggotanya merupakan kelompok 1 dan jaringan kedua adalah jaringan yang anggotanya merupakan kelompok 2. 


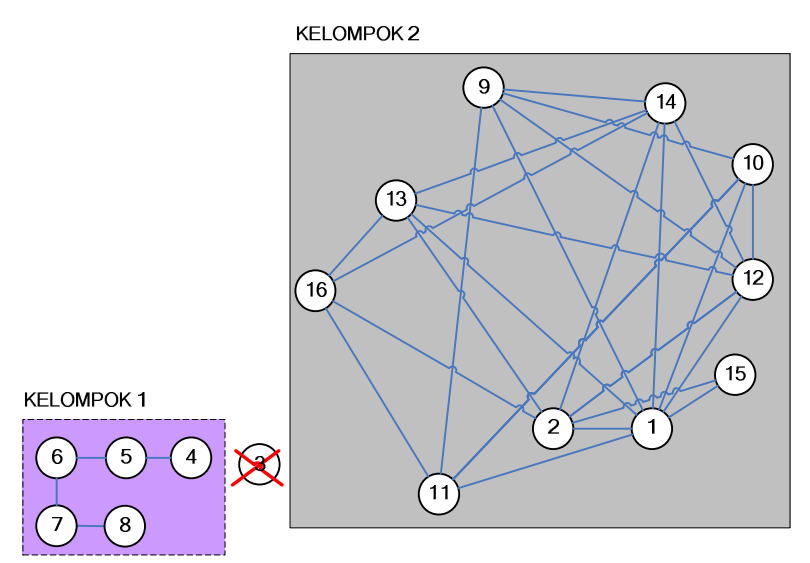

Gambar 10. Graf ketika Node 3 Dihapus : Akun Twitter herlina_lim sebagai Node Awal

\subsubsection{Closeness Centrality}

Gambar 11 merupakan hasil perhitungan closeness centrality sesuai dengan daftar node (seperti gambar 6) dan data relasi (seperti Tabel 2). Berdasarkan hasil perhitungan menggunakan closeness centrality dapat diketahui bahwa yang memiliki nilai closeness centrality paling tinggi adalah akun Twitter dengan user_id 75700454 (node dengan id = 3), yaitu sebesar 0.46875 .

Closeness centrality menunjukkan jarak rata-rata dari node awal ke semua node lain dalam jaringan. Metode ini mampu mengukur seberapa cepat suatu node bisa mengakses node lainnya. Akun Twitter dengan user_id 75700454 (node dengan id = 3) memiliki nilai closeness centrality paling tinggi yaitu sebesar 0.46875 .

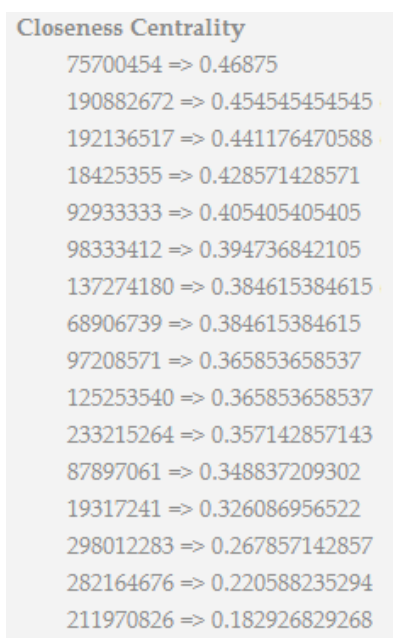

Gambar 11. Closeness Centrality : Akun Twitter herlina_lim sebagai Node Awal 


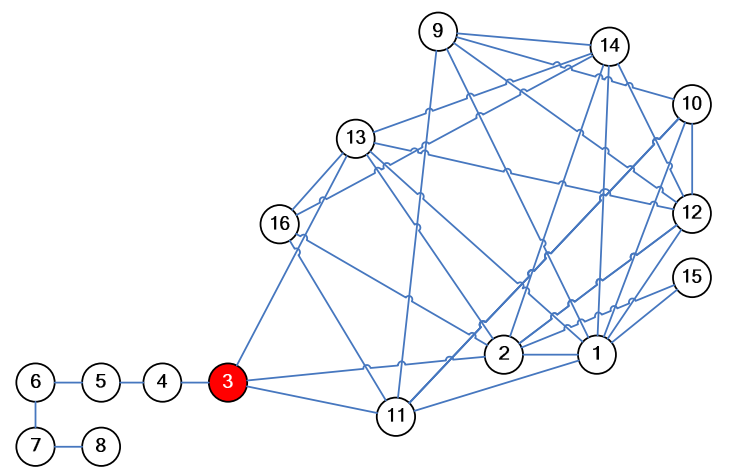

Gambar 12. Analisa Closeness Centrality: Akun Twitter herlina_lim sebagai Node Awal

Pada gambar 12, node berwarna merah yaitu node 75700454 (node dengan id = 3) merupakan node dengan nilai closeness centrality paling tinggi. Akun Twitter atau yang direpresentasikan sebagai node yang memiliki nilai closeness centrality paling tinggi karena node ini memiliki akses yang cepat ke node lainnya, memiliki rute terpendek untuk mengakses node lainnya dan tentunya memiliki visibilitas yang tinggi untuk mengetahui apa yang terjadi di dalam jaringan. Berikut adalah tabel rute node 3 untuk dapat mengakses semua node yang ada di dalam jaringan.

\section{KESIMPULAN}

a) Perhitungan centrality social network Twitter dilihat dari segi friends, yaitu di-follow dan mem-follow telah mampu mewakili proses perhitungan dalam penentuan central dari suatu jaringan.

b) Metode betweenness centrality digunakan ketika pemilik akun Twitter ingin mengetahui node atau akun Twitter mana yang memiliki pengaruh paling kuat di dalam suatu jaringan, sehingga akun Twitter tesebut mampu membuat koneksi ke pasangan atau kelompok lain dalam suatu jaringan.

c) Metode closeness centrality digunakan ketika pemilik akun Twitter ingin mengetahui node atau akun Twitter mana yang memiliki visibilitas paling tinggi dalam mengakses semua node dalam suatu jaringan.

d) Aplikasi perlu dikembangkan hingga tidak perlu lagi mengalami keterbatasan request pengaksesan API Twitter. Dengan ketidakterbatasan request, nantinya aplikasi diharapkan dapat memberikan perhitungan centrality yang lebih akurat karena memperhitungkan seluruh node yang ada di dalam jaringan. Selain itu, penambahan faktor dalam perhitungan centrality bisa juga dilakukan, sehingga tidak hanya melihat dari segi friends saja, tetapi juga melihat dari faktor lain, seperti hastags, mention atau retweet. 
e) Aplikasi dikembangkan dengan menggunakan teknologi web service agar pengembang aplikasi lain dapat merasakan manfaat dari aplikasi ini dan mengembangkan aplikasi ini menjadi lebih baik lagi.

\section{Daftar Pustaka}

Brandes, U. (2001). A Faster Algorithm for Betweenness Centrality. Journal of Mathematical Sociology, 25(2), 163177, diakses 8 Nopember 2011, dari http://www.cs.ucc.ie/ rb4/resources/Brandes.pdf.

Bader, D.A., Kintali, S., Madduri, K. \& Mihail, M. (2007). Approximating Betweenness Centrality. Springer-Verlag, 124-137. Diakses 3 Januari dari http://www.cc.gatech.edu/ kintali/papers/apxbc.pdf

Bohn, A., Feinerer, I., Hornik, K. \& Mair, P. Content-Based Social Network Analysis of Mailing Lists. R Journal, 3(1), 11-18. Diakses 3 Januari dari http://journal.r-project.org/archive/2011-1/RJournal_2011-1_Bohn et al.pdf

Ehrlic, K. \& Carboni, I. Inside Social Network Analysis. Diakses 4 Nopember 2011 dari http://domino.watson.ibm.com/cambridge/research.nsf/0/3f23b2d424be0da6852570a500709975/\$file/tr_200510.pdf

Freeman, L. C. (1978). Centrality in social networks: Conceptual clarification. Social Networks 1, 215-239.

Hanneman, R.A. \& Riddle, M. (2005). Introduction to Social Network Methods. Riverside, CA: University of California, Riverside, Online textbook, diakses 4 Nopember 2011, dari http://faculty.ucr.edu/ hanneman/nettext/.

Huberman, B., Romero, D.M., \& Wu, F. (2009). Social networks that matter: Twitter under the microscope. First Monday, Volume 14, Number 1. Diambil dari http://www.firstmonday.org/htbin/cgiwrap/bin/ojs/index.php/fm/issue/view/274

Kazienko, P. \& Musial, K. (2005). Social Networks. Diakses 4 Nopember 2011, dari http://www.ii.pwr.wroc.pl/ kazienko/pub/2005/social\%20networks.pdf

Tang, L. \& Liu, H. (2010). Community Detection and Mining in Social Media. United States : Morgan \& Claypool Publishers.

Mislove, A., Marcon, M., Gummadi, P.G., Druschel, P. \& Bhattacharjee, B. (2007). Measurement and Analysis of Online Social Networks. Diakses 3 Januari dari http://conferences.sigcomm.org/imc/2007/papers/imc170.pdf

Okamoto, K., Chen, W. \& Li, X. (2008). Ranking of Closeness Centrality for Large-Scale Social Networks. Diakses 3 Januari dari http://research.microsoft.com/en-us/people/weic/faw08_centrality.pdf

Opsahl, T., Agneessens, F., Skvoretz, J., (2010). Node centrality in weighted networks: Generalizing degree and shortest paths. Social Networks 32 (3), 245-251, diakses 10 Nopember 2011, dari http://toreopsahl.com/2010/04/21/article-node-centrality-in-weighted-networks-generalizing-degree-and-shortestpaths/

Tsvetovat, M. \& Kouznetsov, A. (2011). Social Network Analysis for Startup. Sebastopol : O'Reilly Media, Inc.

Wasserman, S. \& Faust, K. (1994). Social Network Analysis : Methods and Applications. United States of America : Cambridge University Press. 